\title{
The Role of Proanthocyanidins Complex in Structure and Nutrition Interaction in Alfalfa Forage
}

\author{
Arjan Jonker ${ }^{1,2, *}$ and Peiqiang Yu ${ }^{1, *}$ \\ 1 College of Agriculture and Bioresources, University of Saskatchewan, 51 Campus Drive, Saskatoon, \\ SK S7N 5A8, Canada \\ 2 Current address: Grasslands Research Centre, AgResearch Ltd., Tennent Drive, Private Bag 11008, \\ Palmerston North 4442, New Zealand \\ * Correspondence: arjan.jonker@agresearch.co.nz (A.J.); peiqiang.yu@usask.ca (P.Y.); \\ Tel.: +64-06-351-8321 (A.J.); +1-306-966-4132 (P.Y.)
}

Academic Editor: Jianhua Zhu

Received: 22 April 2016; Accepted: 17 May 2016; Published: 23 May 2016

\begin{abstract}
Alfalfa (Medicago sativa L.) is one of the main forages grown in the world. Alfalfa is a winter hardy, drought tolerant, $\mathrm{N}$-fixing legume with a good longevity, high yield, high nutrient levels, high digestibility, unique structural to non-structural components ratio, high dry matter intake, and high animal productivity per hectare. However, its main limitation is its excessively rapid initial rate of protein degradation in the rumen, which results in pasture bloat and inefficient use of protein with consequent excessive excretions of nitrogen into the environment. Proanthocyanidins are secondary plant metabolites that can bind with protein and thereby reduce the rate and extent of ruminal protein degradation. However, these secondary metabolites do not accumulate in alfalfa. This review aims to firstly describe the events involved in the rapid release of protein from alfalfa and its effect on ruminant nutrition, environmental pollution, and pasture bloat; secondly, to describe occurrence, structure, functions and benefits of moderate amounts of proanthocyanidin; and finally, to describe the development of alfalfa which accumulates moderate amounts of proanthocyanidins. The emphasis of this review focuses on the role of proanthocyanidins compounds in structure and nutrition interaction in ruminant livestock systems.
\end{abstract}

Keywords: proanthocyanidin; alfalfa; molecular structure and nutrition interaction

\section{Mechanisms for the Release of Protein from Model Alfalfa}

Alfalfa has an excessively rapid initial rate of protein degradation compared to grasses and many legumes like cicer milkvetch (Astragalus cicer L.), sainfoin (Onobrychis viciifolia L.), birdsfoot trefoil (Lotus corniculatus. L.), big trefoil (Lotus pedunculatus L. also known as Lotus major L. and Lotus uliginosus L.) and sulla (Hedysarium coronarium L.) but similar to white clover (Trifolium repens L.; also known as ladino clover), red clover (Trifolium pratense. L) and wheat pasture forage (Triticum aestivum) [1-13]. The main portion of forage proteins is located in leaf mesophyll cells. Soluble proteins can be divided into fraction I proteins (Ribulose-1,5-bisphosphate Carboxylase (Rubisco)) which makes up 30\%-50\% of soluble protein, fraction II protein (several proteins present in small amounts, e.g., plant enzymes and hormones) and chloroplast membrane proteins [14]. On a plant cell level, rapidly degradable nitrogen $(\mathrm{N})$ fractions in plants are non-protein $\mathrm{N}$ (NPN; e.g., $\mathrm{NH}_{4}{ }^{+}$and $\mathrm{NO}_{3}{ }^{-}$, which are mainly found in the plant cell vacuole) and cytoplasmic and soluble protein (mainly Rubisco in alfalfa, which is mainly found in the plant cell chloroplast) [15]. The first mechanism by which these soluble protein fractions are released from the plant cell is ingestive chewing during grazing by livestock. Chewing cracks the cuticle and plasma membrane, destroys mesophyll cells and reduces the forage particle size. During chewing, the $\mathrm{N}$ components from the vacuoles were found to be released at a faster rate 
and to a larger extent than $\mathrm{N}$ from the chloroplasts $[15,16]$. White clover was found to have a faster release of the total cell content and intracellular $\mathrm{N}$ from the plant cell after ingestive chewing (before entering the rumen) than three grass species [17] and alfalfa and red clover had a faster release of soluble proteins after ingestive chewing than sainfoin (Table 1) [18]. Epidermal and mesophyll cells of alfalfa and white and red clover were found to be thinner and less resistant to mechanical rupture than those of birdsfoot trefoil, sainfoin and cicer milkvetch (Table 1) [19-21]. Waghorn et al. [22] found that $\sim 40 \%$ of perennial ryegrass and $\sim 20 \%$ of alfalfa plant cells reached the rumen intact after ingestion, while in general it is believed that over $50 \%$ of plant cells reach the rumen intact [23].

Table 1. Composition, tissue disruption and release of nutrients in leaves of several temperate forage legumes.

\begin{tabular}{|c|c|c|c|c|c|c|}
\hline \multirow{2}{*}{$\begin{array}{c}\text { Item } \\
\text { Parameter }\end{array}$} & \multicolumn{6}{|c|}{ Legume Species } \\
\hline & Alfalfa & $\begin{array}{l}\text { White } \\
\text { Clover }\end{array}$ & $\begin{array}{c}\text { Red } \\
\text { Clover }\end{array}$ & $\begin{array}{c}\text { Birdsfoot } \\
\text { Trefoil }\end{array}$ & Sainfoin & $\begin{array}{c}\text { Cicer } \\
\text { Milkvetch }\end{array}$ \\
\hline \multicolumn{7}{|c|}{ Leaf epidermis + cuticle thickness } \\
\hline Upper $(\mu \mathrm{m})^{1}$ & 1.05 & 1.30 & 1.04 & 1.21 & 1.54 & ND \\
\hline Lower $(\mu \mathrm{m}){ }^{1}$ & 0.93 & 1.31 & 0.89 & 1.22 & 2.04 & ND \\
\hline Upper $(\mu \mathrm{m})^{2}$ & 21 & 26 & 23 & 30 & 25 & 32 \\
\hline \multicolumn{7}{|c|}{ Leaf tissue } \\
\hline Cavities air space (\%) ${ }^{1}$ & 21.2 & 15.8 & 10.8 & 23.8 & 22.6 & $\mathrm{ND}$ \\
\hline Leaf cell wall strength ${ }^{3}$ & weak & weak & $\operatorname{mid}$ & strong & $\operatorname{mid}$ & Mid \\
\hline Leaf tissue strength ${ }^{3}$ & low & low & low & low & high & High \\
\hline Intact leaf mesophyll cells (no.) 4 & 48 & 7 & 1 & 1167 & 570 & 811 \\
\hline Microbial tissue disruption (\%) 5 & 88 & 94 & 89 & ND & ND & 65 \\
\hline \multicolumn{7}{|c|}{ Release of plant cell constituents } \\
\hline Potassium (\%) 6 & 57 & ND & 50 & $\mathrm{ND}$ & 64 & ND \\
\hline Kd conductivity $(\% / \mathrm{h})^{7}$ & 59 & 71 & 75 & 34 & 98 & ND \\
\hline Rubisco (\%) 6 & 46 & ND & 16 & ND & 17 & $\mathrm{ND}$ \\
\hline Soluble protein (\%) 6 & 24 & ND & 20 & $\mathrm{ND}$ & 0 & $\mathrm{ND}$ \\
\hline Proteolytic activity index ${ }^{8}$ & 0.77 & 0.24 & 0.17 & 0.14 & ND & ND \\
\hline
\end{tabular}

ND is not determined. ${ }^{1}$ Epidermis + cuticle thickness and air space were measured in leaf cross sections by electron microscopy [24]; ${ }^{2}$ Epidermis + cuticle thickness was measured in leaf sections under a coverslip in $0.55 \mathrm{mM}$ mannitol solution using photographic transparency (shadow graph with stage micrometer scale) [25]; ${ }^{3}$ Tissue and cell wall strength was determined as chlorophyll released after mechanical disruption by shaking leaves in a tube with glass beads, by a ground glass tissue grinder or by sonication $[25] ;{ }^{4}$ Leaves crushed between two layers of nylon cloth in a mortar with buffer using a pestle. Intact filtrate mesophyll cells were counted with a hemocytometer and light microscope [19]; ${ }^{5}$ Disappearance of green leaf tissue dry matter after $8 \mathrm{~h}$ of ruminal in situ incubations [26]; ${ }^{6}$ Release of plant cell constituent after ingestive mastication [18];

${ }^{7}$ Change in conductivity (rate) due to release of minerals from leaves incubated in $\mathrm{H}_{2} \mathrm{O}$ at $39{ }^{\circ} \mathrm{C}$ [24];

8 Proteolytic activity of fresh plant tissue incubated over a gelatin substrate gel [27].

Some plant cells are still intact and metabolically active when entering the rumen. The conditions in the rumen (temperature, anaerobic nature and microbial colonization) cause a stress reaction in the viable plant cells and result in a release of protein, due to in plant metabolic (e.g., proteinase) activity [23,28]. Proteolytic activity indexes of fresh plant tissue incubated over a gelatin substrate gel was high for Medicago species (mean 0.56, for alfalfa 0.77) and Avena (oat 0.71) but low for the Trifolium (with clover 0.24, red clover 0.17), Triticum (wheat 0.08), Lolium (perennial ryegrass 0.22) and Lotus (birdsfoot trefoil 0.14, big trefoil 0.16) species (Table 1) [27]. Thus, it seems that forages with high ruminal protein degradation do not necessarily have higher proteolytic activity. Kingston-Smith et al. [24] found that ions which are stored in the vacuole (e.g., $\mathrm{Ca}^{2+}, \mathrm{Mg}^{2+}, \mathrm{NH}_{4}{ }^{+}$and $\mathrm{NO}_{3}{ }^{-}$) are released when fresh plant material was incubated in $\mathrm{H}_{2} \mathrm{O}$ at $39^{\circ} \mathrm{C}$ (rumen temperature) without microbes (Table 1). This indicates that membranes become weaker and more permeable over time. Probably, absorption of $\mathrm{H}_{2} \mathrm{O}$ into the plant tissue is involved (cells swell and burst) and allows 
small molecules including ions, soluble carbohydrates and small proteins to escape from the plant cell [24]. The rate at which ions were released was fast for white and red clover and sainfoin, slow for birdsfoot trefoil and intermediate for alfalfa [24].

Intact plant cells have to be ruptured before microbes can enter the cell [29]. Many of these plant cells will be ruptured during re-mastication (rumination) of the cud by the ruminant [16]. When new plant material enters the rumen, microbes will attach to it within five minutes [30]. Microbes will try to invade the plant cell through the stomatal cavity, lenticels and disrupted cells, after which intracellular micro-colonies are formed that can easily disrupt and digest mesophyll cells from the inside out $[29,30]$. The time needed to disrupt leaf tissue and to invade and digest mesophyll cells was shorter for alfalfa, and white and red clover than for birdsfoot trefoil, sainfoin and cicer milkvetch (Table 1) [26,29,31]. The breakdown of plant particles in the rumen was found to be faster for alfalfa than for perennial ryegrass (Lolium perrene L.) [22].

Overall, alfalfa protein was found to have a higher solubility, faster degradation rate and larger extent of ruminal degradation than protein of sainfoin and grasses [8,32]. Besides having plant cells that are more resistant to rupture, legumes like sainfoin, birdsfoot trefoil, big trefoil and sulla contain proanthocyanidins which reduce protein degradation and availability in the rumen [9]. However, proanthocyanidins are not synthesized in the aerial parts of alfalfa and are therefore not present in their forage [10].

However, alfalfa remains popular because it has higher seed germination, higher pasture longevity and higher grazing tolerance compared with legumes like sainfoin, birdsfoot trefoil and cicer milkvetch [33]; compared with grasses, alfalfa has a higher animal dry matter (DM) intake and requires lower fertilizer inputs [5]; and compared with other legumes and grasses, alfalfa has a higher DM yield and animal production per hectare $[3,34]$.

\section{Protein Degradation, Nitrogen to Energy Synchronization Balance and Nitrogen Excretion}

The amino acids that are absorbed in the small intestine of ruminants originate from intestinal digested microbial bodies (protein), intestinal digested dietary protein that escaped rumen microbial degradation and endogenous protein [35]. Microbial-N that enters the small intestine ranges from $60 \%$ to up to $90 \%$ of total $\mathrm{N}$ entering the intestine [36]. For their growth, rumen microbes require $\mathrm{N}$, energy and essential minerals. Carbohydrates are the main source of energy used by microbes [37,38]. Optimal ratio between ruminal available $\mathrm{N}$ and energy required for microbial growth was found to be approximately $25 \mathrm{~g} \cdot \mathrm{N} / \mathrm{kg}$ DM degraded in the rumen [39], $25 \mathrm{~g} \cdot \mathrm{N} / \mathrm{kg}$ organic matter (OM) degraded in the rumen [40] or $32 \mathrm{~g} \cdot \mathrm{N} / \mathrm{kg}$ carbohydrate $(\mathrm{CHO})$ degraded in the rumen [41,42].

In freshly harvested alfalfa at different stages of growth, rumen degradable N:DM ratio ranged from $31-49 \mathrm{~g} \cdot \mathrm{N} / \mathrm{kg}$ DM with extent of ruminal DM degradation ranging from $55 \%$ to $80 \%$ which is lower than the range of $76 \%$ to $90 \%$ for extent of ruminal crude protein (CP) degradation (Table 2). NRC [43] recommends that a total diet consists for $14 \%-18 \%$ of CP with $62 \%-65 \%$ of CP consisting of rumen degradable $\mathrm{CP}$, while Broderick et al. [36] found (analysis of 32 studies with 122 diets) dietary $\mathrm{CP}$ of $15 \%$ from which $70 \% \mathrm{CP}$ in the rumen degradable form to be optimum. The forage $\mathrm{CP}$ content, rumen degradable $\mathrm{CP}$ and imbalance between ruminal degradable $\mathrm{N}$ and $\mathrm{DM}$ tends to decrease with advancing plant maturity stages (Table 2). 
Table 2. Protein quality characteristics for freeze-dried alfalfa, grass and sainfoin.

\begin{tabular}{|c|c|c|c|c|c|c|c|}
\hline \multirow{2}{*}{$\begin{array}{c}\text { Item } \\
\text { Parameter }\end{array}$} & \multirow{2}{*}{$\mathrm{RD}_{\mathrm{DM}}{ }^{1}$} & \multirow{2}{*}{$\mathrm{CP}$} & \multicolumn{3}{|c|}{ Ruminal CP Degradation } & \multirow{2}{*}{$\mathrm{RD}_{\mathrm{N}}: \mathrm{RD}_{\mathrm{DM}}{ }^{1}$} & \multirow{2}{*}{ References } \\
\hline & & & Rate & Solubility & Extent & & \\
\hline Unit & \multicolumn{2}{|l|}{ (\%DM) } & $(\% / h)$ & \multicolumn{2}{|c|}{$(\% \mathrm{CP})$} & (g/kg) & \\
\hline \multicolumn{8}{|c|}{ Alfalfa } \\
\hline Vegetative & $65-80$ & $20-27$ & $15-34$ & $40-60$ & $80-90$ & $40-49$ & {$[32,44-47]$} \\
\hline Bud & $55-77$ & $17-21$ & $15-29$ & $41-47$ & $80-83$ & $34-41$ & {$[32,45,47]$} \\
\hline Early flower & $57-59$ & $17-19$ & $17-31$ & $40-46$ & $75-81$ & $37-41$ & {$[32,44,45]$} \\
\hline Full flower & $58-60$ & $15-16$ & $12-14$ & $41-47$ & $73-79$ & $31-32$ & {$[45,47]$} \\
\hline Early pod & $55-58$ & 16 & $15-17$ & 52 & $78-82$ & 36 & {$[46,47]$} \\
\hline \multicolumn{8}{|c|}{ Grass } \\
\hline Tillering & $66-70$ & $20-26$ & 17 & $32-45$ & $79-82$ & $39-50$ & [45] \\
\hline Elongation & $52-62$ & $15-21$ & $10-15$ & $27-47$ & $68-82$ & $31-47$ & [45] \\
\hline Heading & $50-60$ & $12-14$ & $11-12$ & $36-56$ & $70-76$ & $26-30$ & [45] \\
\hline Flowering & $38-40$ & $7-10$ & $7-11$ & $43-53$ & $61-70$ & $18-27$ & [45] \\
\hline \multicolumn{8}{|c|}{ Sainfoin } \\
\hline Vegetative & 55 & 16 & 11.3 & 16 & 59 & 28 & [32] \\
\hline Early flower & 48 & 12 & 14.1 & 20 & 63 & 26 & {$[32]$} \\
\hline
\end{tabular}

The rate and extent of alfalfa protein degradation are not only excessive, but the supplied amount of rumen available energy from alfalfa is also not sufficient to support optimal conditions for microbial growth. Degradation of fibrous carbohydrates is slower in forages than for non-fiber carbohydrates (NFC). For alfalfa at three stages of growth (pre/early-bud, late-bud and early flower stages) fractional degradation rate of neutral detergent fiber (NDF) ranged from $3 \%-8 \% / \mathrm{h}$ which is slower than the range of $7.8 \%-16 \% / \mathrm{h}$ found for NFC in two studies $[8,48]$. The CP properties of alfalfa improve with advancing maturity, but NDF content will increase as well, which counterbalances the improved CP properties in a negative fashion. Therefore, the imbalance between the release of $\mathrm{N}$ and energy in the rumen can be decreased by decreasing protein content, solubility or degradation rate and/or increasing content, solubility or degradation rate of carbohydrates.

The excess protein released into the rumen above microbial requirements is mainly deaminated into ammonia $\left(\mathrm{NH}_{3}\right)$, energy and volatile fatty acids (mainly propionate and branch chain fatty acids) by rumen microbes $[49,50]$. The energy is used for microbial growth and excess ruminal $\mathrm{NH}_{3}$ is absorbed across the rumen wall and converted in the liver mainly into urea at the cost of energy [51,52]. Urea-N can re-enter the rumen via secreted saliva or by direct diffusion/active transport from blood into the rumen where it is converted back into $\mathrm{NH}_{3}$ by ureolytic bacteria $[53,54]$. When sufficient energy is available, $\mathrm{NH}_{3}$ is used for microbial protein synthesis; otherwise when energy is insufficient, $\mathrm{NH}_{3}$ will be mainly lost to the animal and excreted via urea in the urine [51,55]. At different levels of protein intake from total mixed rations with different levels of $\mathrm{N}$ and ruminal $\mathrm{N}$ degradability and different forage:concentrate ratios, urine-N excretion ranges from $133-592 \mathrm{~g} / \mathrm{kg} \cdot \mathrm{N}$ intake [56]. Excreted urinary urea- $\mathrm{N}$ is easily volatilized to $\mathrm{NH}_{4}$ or converted to $\mathrm{NO}_{3}{ }^{-}$which contribute to environmental acidification and eutrophication, respectively $[51,56]$. In addition to these environmental drawbacks, high blood $\mathrm{NH}_{3}$ and urea levels also have a negative effect on reproduction and fertility of cattle [52].

Valkeners et al. [57] found that an unsynchronized $\mathrm{N}$ to energy supply during parts of the day can be balanced by urea- $\mathrm{N}$ recycling when the overall $\mathrm{N}$ to energy supply is balanced on a daily basis. Some recent research suggests that diets with oscillating dietary protein (unsynchronized but balanced) are utilized more efficiently, probably because of increased utilization of recycled urea-N into microbial cells [58-60]. However, as described before, for alfalfa the release of excess $\mathrm{N}$ relative to energy in the rumen is both unsynchronized and unbalanced and will lead to an inefficient use of 
dietary $\mathrm{N}$ by the animal and excessive excretion of $\mathrm{N}$ into the environment. Conversion of protein into energy results not only in protein losses for the animal but it also yields less energy (13.6 mol. ATP $/ \mathrm{kg}$ $\mathrm{CP}$ ) than derived from fermentation of carbohydrates (23.9-27.3 mol. ATP/ $\mathrm{kg} \mathrm{CHO}$ ) for microbial growth [49,61]. Moreover, excessive ruminal protein degradation results in a reduced portion of dietary protein escaping to the lower digestive tract, a process that is required for optimum animal performance of high producing cattle $[62,63]$.

\section{Alfalfa and Pasture Bloat}

Pasture bloat arises from rumen fermentation gases, which become trapped in a viscous stable protein foam that prevents normal eructation of microbial fermentation gasses by the animal $[64,65]$. The accumulation of gas in the rumen causes dissention of the rumen and exerts pressure on organs like the lungs, heart and vagus nerve. This can lead to the death of the animal under severe conditions $[66,67]$. Even considering the relatively low number of animals grazed on alfalfa in North America, cattle mortality due to pasture bloat was estimated to be as high as $1.5 \%$ with economic losses estimated at $\$ 125$ million a year $[68,69]$.

Rumen conditions that favor the formation of stable protein foams include the nature of the surface active materials at the gas-liquid interface provided by the rumen environment $(\mathrm{pH}$, viscosity, ionic composition, soluble protein concentration, and microbial species composition) and adequate gas production [33,70]. Table 3 shows some rumen and animal characteristics of cattle prone to pasture bloat compared with animals that do not bloat on the same pasture.

Table 3. Characteristics of cattle prone to pasture bloat compared with non-bloating animals.

\begin{tabular}{cc}
\hline Bloating Cattle & References \\
\hline Decreased dry matter intake & {$[71,72]$} \\
Decreased saliva production & {$[73,74]$} \\
Increased saliva viscosity & {$[74]$} \\
Decreased clearance rate liquid and particles & {$[71,75]$} \\
\hline Rumen liquid of bloating cattle & References \\
\hline Decreased $\mathrm{Na}^{+}$ & {$[76]$} \\
Increased Ca ${ }^{2+}, \mathrm{Mg}^{2+}$ and $\mathrm{K}^{+}$ & {$[76]$} \\
Increased viscosity & {$[77,78]$} \\
Increased ethanol precipitated film with higher CP content & {$[79,80]$} \\
Increased buoyancy of particle matter & {$[71,75]$} \\
Increased small particle retention & {$[71,75,81]$} \\
Increased foam volume and stability & {$[64,65]$} \\
Similar protein concentration & {$[75,81]$} \\
\hline
\end{tabular}

Increased viscosity of the rumen liquid may be due to increased protein, carbohydrate, and nucleic acid concentrations [79], viscous saliva [73] and slime produced by certain microbes $[80,82]$. The increased viscosity of rumen liquid makes it more difficult for feed particles to move within the liquid and increases particle matter buoyancy with consequent increased particle retention (chlorophyll) in the rumen $[71,75,83]$. The viscous film at the gas-liquid interface can be harvested by methanol precipitation. This film of bloating cattle on legume pastures (white clover) had a $\mathrm{CP}$ and $\mathrm{CHO}$ composition (63\% and $15 \%$, respectively) similar to foam from a bloating animal $[79,84]$.

Because positive correlations between pasture bloat and alfalfa soluble protein content have been reported frequently, it is generally accepted that rapid initial release of protein from alfalfa is involved in its propensity to cause pasture bloat $[14,72,85]$. Soluble proteins, which are rapidly released into the rumen liquid, are thought to form a viscous film at the gas-liquid interface and this could act as an active agent for the formation of foam that might result in frothy bloat $[72,80]$. The proteolytic bacterial strain Streptococcus bovis (S. bovis) cultured on a protein extract (from wheat forage) was found to have a high growth rate and to produce large amounts of slime [80]. Proteolytic microbial populations in 
the rumen of cattle grazing perennial ryegrass/white clover pasture were found to consist of $61 \%$ S. bovis like strains [86]. Thus, part of the viscous film formed at the gas-liquid interface might originate from protein degrading microbes that produce a viscous slime. However, in vitro foam stability of aqueous leaf extracts was previously found to be related to in vitro foam stability from rumen liquid of bloating animals and to in vivo bloat incidence in cattle $[87,88]$. This suggests that slime produced by microbes are not required for the formation of a viscous film at the gas-liquid interface and thus not required for the formation of stable foam in the rumen.

Incidence of bloat in grazing cattle is higher when offering alfalfa at a vegetative stage than at advanced stages of maturity [89]. Vegetative alfalfa has a higher leaf to stem ratio, higher protein content and higher digestibility compared with more mature alfalfa [90,91]. In general, pasture bloat occurs within two to three hours after moving cattle to a bloat inducing pasture [33,92]. Cattle graze the pasture canopy from the top to the bottom of the plants removing around $35 \%$ of the sward height per bite [93]. The top of the canopy has a higher leaf to stem ratio than the bottom of the canopy [91]. So, at the initial stage of grazing cattle consume mainly leaves. Leaves have a higher soluble protein content, higher ruminal digestibility, lower fiber content and higher foaming properties compared with stems $[90,94,95]$. Thus the higher soluble protein content and digestibility in leaves and vegetative growth might explain the higher bloat incidence shortly after allocating cattle to a new pasture or to a vegetative pasture. However, the protein content in rumen liquid of bloating cattle was not different than that of non-bloating cattle on the same pasture. This suggests that other components are involved in the stabilization of bloat related foam $[68,75,81]$.

Alfalfa leaves and younger vegetative growth were found to have a higher saponin content compared with stems and more mature growth [96]. Saponins form a stable froth when shaken in water. When saponins are released into the rumen liquid, they reduce smooth muscle activity and thereby reduce rumen motility. This reduces the rumen digesta passage rate and may directly reduce or stop the eructation reflex $[97,98]$. Saponins released in the rumen liquid are extensively degraded by saponin degrading microbes (e.g., Butyrivibrio) which were found to produce a viscous slime [82]. However, cattle grazing a high saponin $(1.9 \%)$ alfalfa cultivar were no more prone to pasture bloat than cattle grazing a low saponin $(0.8 \%)$ cultivar, and administration of alfalfa juice with saponins to cattle and sheep did not produce bloat $[99,100]$. Besides, bloat occurs on wheat pastures as well and wheat forage does not contain saponins [101,102]. However, some reported studies detected bloat signals like distention of the rumen and animal distress when administering alfalfa saponin extracts to ruminants [98,103]. These findings suggest that saponins might be involved in some cases of frothy bloat, but they are not required for the formation of stable foam in the rumen. Saponin content, ratio between sapogenins and sapogenin structure differ among alfalfa cultivars and might determine the propensity to develop pasture bloat $[96,104,105]$. Little is known about the effect of environment, season, climatic conditions and growth conditions on saponin content, the ratio between individual sapogenins and on sapogenin structure in alfalfa [105].

A number of factors appear to influence foam strength. Previously, foam strength was found to be maximum around $\mathrm{pH} 5$ to $6[106,107]$. Positively-charged ions $\left(\mathrm{Ca}^{2+}\right.$ and $\left.\mathrm{Mg}^{2+}\right)$ may increase foam stability by attracting negatively charged soluble proteins in rumen liquid $[66,76,108]$. Pectins and simple saccharides are also thought to increase the viscosity of rumen liquid $[88,109]$ while higher fiber content is associated with a lower forage digestibility, a condition which reduces the amount of foaming compounds released [110]. Soluble proteins, small particles and positively charged ions may form a complex at the gas-liquid interface and stabilize ruminal foam [68,75].

\section{Management Strategies to Reduce Bloat Incidence on Alfalfa Pastures}

Grazing management strategies found to reduce the incidence of pasture bloat include allocating cattle to a new pasture in the afternoon instead of the early morning, continuous grazing instead of interrupted grazing, strip grazing to force the animals to graze the whole plants in a short period (lower part of the plant contains less protein and is less digestible) $[72,111]$ and offering alfalfa in an 
advanced stage of maturity [89]. Even though these grazing management strategies are associated with decreased severity and occurrence of bloat, pasture bloat can occur in the afternoon, with continuous grazing and at full bloom [33].

Anti-bloat agents, which contain oils and alfalfa forage lipids, destabilize foam related to bloat [101,112]. Non-bloating alfalfa forage has a higher lipid (mainly located in the chloroplast) content relative to protein [112]. Anti-foaming agents, like oils and detergents, have been used with success to prevent pasture bloat, but their effectiveness depends on intake, which cannot be guaranteed when supplied as free choice $[67,111]$.

The risk of pasture bloat is negligible when cattle graze pastures with grass. Feeding corn silage or grass hay to cattle before turning them onto alfalfa pasture reduces the incidence of bloat substantially $[113,114]$. However, beef cattle and sheep are usually not (or not regularly) supplemented during the grazing season. Moreover, in general, grass pastures have a lower nutritional value, lower DM yield and higher fertilization costs compared to alfalfa under North American conditions [33]. Therefore, alfalfa can be grown in mixtures with grass so that livestock can benefit from the positive attributes of both forage families, but even mixtures have limitations. Orchard grass-alfalfa mixtures $(25 \%-50 \%$ grass $)$ reduced the incidence of bloat, but did not fully eliminate it $[115,116]$, likely because of plant selection by cattle. Rutter et al. [117] found that cattle and sheep grazed on mixed grass-legume pastures (perennial ryegrass/white clover) prefer eating legumes (ca. $70 \%$ ), especially in the morning.

\section{Selection of Alfalfa with Reduced Protein Degradation}

From 1979 onwards, selection at Agriculture and Agri-Food Canada for alfalfa with a low initial rate of degradation was conducted by incubating the top $15 \mathrm{~cm}$ of alfalfa plants in situ in nylon bags for $4 \mathrm{~h}$ in the rumen of fistulated cows. The population of the fourth selection cycle was released as a new cultivar in 1997 under the name AC Grazeland [118]. AC Grazeland harvested at a vegetative stage had a reduced initial rate of degradation, increased NDF and acid detergent fiber content, lower leaf-to-stem ratio; increased leaf epidermis and mesophyll wall thickness compared with the alfalfa cultivar Beaver [118-121]. In grazing experiments, AC Grazeland at the vegetative stage reduced the incidence and severity of pasture bloat on average by $56 \%$ compared to Beaver but it did not fully prevent it $[111,118,122]$. In vitro foam stability was reduced for leaf extract from AC Grazeland compared with other alfalfa cultivars [123]. A similar selection program in Argentina [124] produced a third selection cycle population called Carmina, which reduced the incidence and severity of pasture bloat by $25 \%$ [125]. Thus further improvements in protein degradation characteristics are required in order to develop a bloat safe alfalfa cultivar.

A range of methods has been be used for rapid selection of alfalfa samples for different protein properties. The in vitro inhibitor method showed a difference of 41,38 and $31 \mathrm{~g} / \mathrm{kg} \cdot \mathrm{N}$ and $4.2 \% / \mathrm{h}$ for soluble $\mathrm{N}$, potentially degradable $\mathrm{N}$, ruminal escape protein and degradation rate, respectively, among 19 alfalfa cultivars from different parts of the world while each had a similar total $\mathrm{N}$ content [126]. Using the same method, rumen undegradable $\mathrm{N}$ differed $21 \mathrm{~g} / \mathrm{kg} \cdot \mathrm{N}$ and $\mathrm{N}$ degradation rate differed by $1.9 \% / \mathrm{h}$ among 27 Canadian cultivars grown in two years and in vitro DM digestibility (Tilley and Terry method) of these same cultivars differed by $38 \mathrm{~g} / \mathrm{kg}$ DM [121]. Protein fractions generated by wet chemical analysis as used in the Cornell Net Carbohydrate and Protein System correlated with in vitro inhibitor rumen undegradable CP [127].

Individual amino acids and individual proteins differ in ruminal degradation rate. Thus, protein degradation rates could be decreased by increasing the expression of genes that produce amino acids with a low degradation rate $[128,129]$. Protein secondary and tertiary structures affect the extent and rate of rumen degradability as well. The number of disulfide (S-S) bonds in the tertiary protein structure was found to affect the extent and rate of protein degradation [130,131]. Sulfur containing amino acids have disulfide bonds, which are less degradable in the rumen. Fourier Transformed Infrared (FTIR) vibration spectroscopy determined that protein with more $\alpha$-helices relative to $\beta$-sheets and protein with less amide I relative to amide II vibration had reduced ruminal 
protein degradability $[132,133]$. The previously mentioned AC Grazeland had more $\alpha$-helices relative to $\beta$-sheets and protein with less amide I relative to amide II compared with other cultivars [123] and AC Grazeland tended to have a lower rumen degradability of protein compared with other alfalfas [134]. There was little difference between transgenic alfalfa leaves and their non-transgenic parents in terms of protein molecular structures [123,135], while in vitro fermentation characteristics differed [136]. The $\alpha$-helices: $\beta$-sheets ratio decreased and amide I:amide II ratio increased with advancing maturity of alfalfa hay [137]. The $\alpha$-helices: $\beta$-sheets ratio related positively with protein rumen degradability and predicted nutrient supply to cattle while it correlated negatively with amid I:amid II ratio [137], which is opposite from the expectation described above. Further research is required to improve the application of FTIR to predict the protein value of feeds. Twenty-six alfalfa proteins from several genotypes of three alfalfa populations showed a range of degradability using fluorescence two-dimensional gel electrophoresis combined with mass spectrometry [138]. For nine of these proteins, more than $75 \%$ remained after $45 \mathrm{~min}$ of in situ ruminal incubation, while twelve other proteins where more than $50 \%$ digested after $45 \mathrm{~min}$, and others were intermediate. After $120 \mathrm{~min}$ incubation, $80 \%$ remained from four proteins and less than $50 \%$ remained from 14 proteins. The main protein ( $41 \%$ of the original sample) with a low degradability after $120 \mathrm{~min}$ was the Rubisco large subunit [138]. Previously the Rubisco large subunit was found to have a faster ruminal degradation rate than the Rubisco small subunit $[139,140]$. Selecting alfalfa plants based on protein structure or protein composition might offer new ways to develop alfalfa with a reduced ruminal degradation rate. Proanthocyanidins are also known to reduce the rate and extent of ruminal protein degradation [9].

\section{Alfalfa-Proanthocyanidin Containing Forage Mixtures}

Proanthocyanidins do not usually accumulate in alfalfa forage [10], but they can be introduced into livestock diets by mixing proanthocyanidin containing forage species into alfalfa pastures [141]. In grazing experiments, mixed alfalfa pastures with $9.1 \%$ to $35.5 \%$ sainfoin $(1.8$ to $8.6 \mathrm{~g} / \mathrm{kg}$ proanthocyanidin) reduced the incidence of bloat as the percentage of sainfoin in the pasture increases. Cattle grazing this mixed pasture had decreased ruminal ammonia concentration, decreased acetate:propionate ratio and decreased ruminal proteolytic activity [141]. However, mixing sainfoin into alfalfa pastures does not fully eliminate pasture bloat [141,142], likely because of competition between plant species (changing the proanthocyanidin content ingested by the animal) and/or plant selection by grazing cattle [141]. Performance of grazing sheep was improved in birdsfoot trefoil/alfalfa mixed pastures $(0.8 \%-1.0 \%$ proanthocyanidin) compared with pure alfalfa pastures, but was superior in pure birdsfoot trefoil pastures ( $3 \%-6 \%$ proanthocyanidin) [143]. Many other beneficial effects on animal health and production were found when grazing proanthocyanidin containing forages like birdsfoot trefoil (Table 4). When forage contains up to $9 \%$ proanthocyanidins, approximately $90 \%$ of it complexes with host plant constituents (mainly protein) during digestion and only $10 \%$ is released as free-proanthocyanidins [144]. Free-proanthocyanidins are required in the mixture to improve the degradation characteristics of non-proanthocyanidin accumulating forage species; its limitation may explain the limited benefit of mixing proanthocyanidin accumulating forages with alfalfa. Proanthocyanidin content of the co-forage should probably be high ( $>9 \%)$ in order to be successful at affecting ruminal degradability from mixtures with alfalfa [9]. It would seem that a problem with grazing mixed pasture is animal selection (palatability of the added forage) that would make it difficult to truly assess the impact of intercropping to control bloat. Therefore it would be beneficial to develop alfalfa that produces moderate amounts of proanthocyanidin in its forage. 
Table 4. Effect of feeding birdsfoot trefoil and big trefoil with proanthocyanidin concentrations between $2 \%$ and $5 \%$ on performance of sheep and cattle.

\begin{tabular}{cc}
\hline Trait & References \\
\hline \multicolumn{1}{c}{ Sheep } & \\
\hline $\begin{array}{c}\text { Increased wool growth } \\
\text { Increased milk yield }\end{array}$ & {$[145-148]$} \\
Cattle & {$[146]$} \\
Increased ovulation rate/number lambs born & {$[148,149]$} \\
Increased lamb weight gain & {$[147,150]$} \\
Reduced intestinal parasite load & {$[148,151]$} \\
\hline & \\
\hline Increased milk production & {$[152-155]$} \\
Increased milk protein production & {$[154,155]$} \\
Decreased milk fat production & {$[155]$} \\
Reduced milk saturated fatty acids & {$[156]$} \\
Increased milk $\omega-3$ fatty acids & {$[156]$} \\
Increased weight gain & {$[157]$} \\
\hline
\end{tabular}

\section{Relation of the Lower Flavonoid Pathway to Stimulate Anthocyanin and Proanthocyanidin}

The synthesis of proanthocyanidin in the flavonoid pathway is regulated by many regulatory genes at the transcriptional level. The regulatory genes involved in the flavonoid pathway code for $\beta$-helix-loop-helix proteins ( $\beta H L H), M y b$-like proteins and WD40-like proteins.

In maize (Zea mays), several genes regulate its flavonoid pathway. These code for $\beta H L H$ proteins (Sn, B-Peru, and Lc), Myb-like proteins (C1) and WD40-like proteins (PAC1) [158]. Over-expression of the maize $\beta H L H$ gene in birdsfoot trefoil increased the number of proanthocyanidin-containing cells by 50 fold and its leaf concentration was increased by $1 \%$ [159].

Alfalfa contains proanthocyanidin in the seed coat [160] proving the existence of the flavonoid pathway in alfalfa. Recently, alfalfa was transformed with the Myb-like legume anthocyanin-producting gene (LAP1) from Medicago truncatula [161]. Small but stable amounts of proanthocyanidin-like structures without (-)-epicatechin extension units and multiple glycosylated conjugates of cyanidin were detectable in this deep-purple LAP1-transformed alfalfa. In addition, large numbers of regulatory genes involved in the flavonoid pathway were induced [161].

Ray et al. [162] transformed alfalfa with three flavonoid pathway regulatory genes of maize $(C 1, L c$, and B-Peru). Only the $L c(\beta H L H)$ regulatory gene stimulated the accumulation of anthocyanidin under field conditions (97-136 $\mu \mathrm{g} / \mathrm{g}$ DM) [163] and anthocyanidin (152 $\mu \mathrm{g} / \mathrm{g}$ fresh) and proanthocyanidin $(307 \mu \mathrm{g} / \mathrm{g}$ fresh; $1.5 \mathrm{~g} / \mathrm{kg} \mathrm{DM})$ after indoor shift to high light intensity [162]. A detailed phytochemical analysis of these genotypes indicated variation in flavone glycosides between the $L c$ (A01-88)-genotypes and in one genotype a two-fold increase in total saponin content (Oleszek and Gruber, AAFC, Saskatoon, Canada; unpublished data). Three of these $L c$-alfalfa genotypes grown in the field had a reduced initial rate of nitrogen and DM degradation in vitro in rumen liquid compared to their non-transgenic parent genotype, but the extent of $\mathrm{N}$ and DM degradation was unaffected [163]. These $L c$-genotypes did not survive the winter in western Canada and therefore three $L c$-genotypes were crossed, each with different local commercial alfalfa cultivars to be able to do a study over multiple year in the field. As with the parental Lc-genotypes, accumulation of extractable and unextractable proanthocyanidin was not detectable in the forage $[164,165]$ while anthocyanidin accumulated in all three years of the study in all three populations ranging from $42.5-349.0 \mathrm{\mu g} / \mathrm{g}$ DM $[123,134,136,164]$, which was a broader and higher range than the $97-136 \mu \mathrm{g} / \mathrm{g}$ DM range for the parental $L c$-genotypes [163]. Compared with parental non-transgenic alfalfa cultivars, these anthocyanidin accumulating $L c$-alfalfa crosses had lower protein and higher carbohydrate content [164,165], reduced rate of fermentation and effective degradability [136] higher predicted nutrient availability for animal production [134] and reduced bloat related foaming properties 
in vitro [123]. These suggest that anthocyanidin might also hold promise to improve the nutritive properties of alfalfa.

However, proanthocyanidin concentration in the $L A P 1$-alfalfa and $L c$-alfalfa genotypes was far below levels needed to guarantee bloat safety and to beneficially affect protein metabolism. Hence, further improvements are required to develop an alfalfa cultivar that accumulates a higher amount of proanthocyanidin in its forage. New crosses have been made between $L c$-alfalfa genotypes (with multiple copies of the Lc gene) and Lc-alfalfa crossed with LAP1-alfalfa and C1-alfalfa in an attempt to enhance the flavonoid pathway and these new populations are currently under evaluation [166].

\section{Conclusions}

Proanthocyanidin is beneficial in moderate concentrations in temperate legume and ryegrass pastures because of its ability to bind with dietary protein in the rumen, which improves protein utilization and overall animal performance, prevents pasture bloat and reduces environmental impact from pastoral farming systems. However, agronomic performance of proanthocyanidin accumulating legumes is inferior to alfalfa and ryegrass/white clover pastures, which limits their adoption by farmers. Progress is made in enhancing the flavonoid pathway in alfalfa through genetic engineering, but accumulation of proanthocyanidin in the forage remains low to date and public concern might limit adoption of successful cultivars. In addition, improvement in the agronomic performance of proanthocyanidin accumulating legumes is in progress for both monocultures and in mixtures with other forages like alfalfa.

Acknowledgments: The Ministry of Agriculture Strategic Research Chair feed research programs (Peiqiang Yu) have been supported by grants from the Natural Sciences and Engineering Research Council of Canada (NSERC-DG and CRD), Ministry of Agriculture Strategic Research Chair Program Fund, Agricultural Development Fund (ADF), SaskCanola, SaskMilk, SaskPulse, WGRF etc. The authors thank Margaret Gruber (Agriculture and Agri-Food Canada, Saskatoon, Canada) and Yuxi Wang (Agriculture and Agri-Food Canada, Lethbridge, AB, Canada) and other student advisory committee members for research collaboration and contributions.

Author Contributions: Arjan Jonker wrote the review as part of his $\mathrm{PhD}$ thesis and Peiqiang Yu wrote a section of the review, reviewed the paper, edited the article to the journal format and managed the article submission till publication.

Conflicts of Interest: The authors declare no conflict of interest.

\section{References}

1. Hanson, A.A.; Barnes, D.K.; Hill, R.R. Alfalfa and Alfalfa Improvement. Agronomy No. 29; The American Society of Agronomy: Madison, WI, USA, 1988.

2. McMahon, L.R.; McAllister, T.A.; Berg, B.P.; Majak, W.; Acharya, S.N.; Popp, J.D.; Coulman, B.E.; Wang, Y.; Cheng, K.J. A review of the effects of forage condensed tannins on ruminal fermentation and bloat in grazing cattle. Can. J. Plant Sci. 2000, 80, 469-485. [CrossRef]

3. Popp, J.D.; McCaughey, W.P.; Cohen, R.D.H.; McAllister, T.A.; Majak, W. Enhancing pasture productivity with alfalfa: A review. Can. J. Plant Sci. 2000, 80, 513-519. [CrossRef]

4. Yu, P.; Christensen, D.A.; McKinnon, J.J.; Markert, J.D. Effect of variety and maturity stage on chemical composition, carbohydrate and protein subfractions, in vitro rumen degradability and energy values of timothy and alfalfa. Can. J. Anim. Sci. 2003, 83, 279-290. [CrossRef]

5. Thornton, R.F.; Minson, D.J. The relationship between apparent retention time in the rumen, voluntary intake and apparent digestibility of legume and grass diets in sheep. Aust. J. Agric. Res. 1973, 24, 889-898. [CrossRef]

6. Allen, M.S. Effects of diet on short-term regulation of feed intake by lactating dairy cattle. J. Dairy Sci. 2000, 83, 1598-1624. [CrossRef]

7. Broderick, G.A. Desirable characteristics of forage legumes for improving protein utilization in ruminants. J. Anim. Sci. 1995, 73, 2760-2773. [PubMed]

8. Yu, P.; McKinnon, J.J.; Christensen, D.A. The ratios of degradation characteristics of forages in the rumen of dairy cows: Effect of variety and stage of maturity. J. Sci. Food Agric. 2004, 84, 179-189. [CrossRef] 
9. Barry, T.N.; McNabb, W.C. The implications of condensed tannins on the nutritive value of temperate forages fed to ruminants. Br. J. Nutr. 1999, 81, 263-272. [PubMed]

10. Goplen, B.P.; Howarth, R.E.; Sarkar, S.K.; Lesins, K. A search for condensed tannins in annual and perennial species of Medicago, Trigonella, and Onobrychis. Crop Sci. 1980, 20, 801-804. [CrossRef]

11. Hoffman, P.C.; Sievert, S.J.; Shaver, R.D.; Welch, D.A.; Combs, D.K. In situ dry matter, protein, and fiber degradation of perennial forages. J. Dairy Sci. 1993, 76, 2632-2643. [CrossRef]

12. Djouvinov, D.S.; Nakashima, Y.; Todorov, N.; Pavlov, D. In situ degradation of feed purines. Anim. Feed Sci. Technol. 1998, 71, 67-77. [CrossRef]

13. Julier, B.; Guines, F.; Emile, J.-C.; Huyghe, C. Variation in protein degradability in dried forage legumes. Anim. Res. 2003, 52, 401-412. [CrossRef]

14. Howarth, R.E.; Sarkar, S.K.; Fesser, A.C.; Schnarr, G.W. Some properties of soluble proteins from alfalfa (Medicago sativa) herbage and their possible relation to ruminant bloat. J. Agric. Food Chem. 1977, 25, 175-179. [CrossRef]

15. Boudon, A.; Peyraud, J.L. The release of intracellular constituents from fresh ryegrass (Lolium perenne L.) during ingestive mastication in dairy cows: Effect of intracellular constituent, season and stage of maturity. Anim. Feed Sci. Technol. 2001, 93, 229-245. [CrossRef]

16. Boudon, A. Effects of stage of maturity and chop length on the release of cell contents of fresh ryegrass (Lolium perenne L.) during ingestive mastication in steers fed indoors. Anim. Res. 2002, 51, 349-365. [CrossRef]

17. Acosta, A.; Boudon, A.; Peyraud, J.L. Species and variety of herbage affects release of cell contents during ingestive mastication in dairy cows fed indoors. Anim. Feed Sci. Technol. 2007, 132, 28-48. [CrossRef]

18. Mangan, J.L.; Vetter, R.L.; Jordan, D.J.; Wright, P.C. The effect of the condensed tannins of sainfoin (Onobrychis viciaefolia) on the release of soluble leaf protein into the food bolus of cattle. Proc. Nutr. Soc. 1976, 35, 95A-97A. [PubMed]

19. Howarth, R.E.; Goplen, B.P.; Fesser, A.C.; Brandt, S.A. A possible role for leaf cell rupture in legume pasture bloat. Crop Sci. 1978, 18, 129-133. [CrossRef]

20. Lees, G.L.; Howarth, R.E.; Goplen, B.P.; Fesser, A.C. Mechanical disruption of leaf tissues and cells in some bloat-causing and bloat-safe forage legumes. Crop Sci. 1981, 21, 444-448. [CrossRef]

21. Lees, G.L. Cuticle and cell wall thickness: Relation to mechanical strength of whole leaves and isolated cells from some forage legumes. Crop Sci. 1984, 24, 1077-1081. [CrossRef]

22. Waghorn, G.C.; Shelton, I.D.; Thomas, V.J. Particle break down and rumen digestion of fresh ryegrass (Lolium perenne L.) and lucerne (Medicago sativa L.) fed to cow during a restricted feeding period. Br. J. Nutr. 1989, 61, 409-423. [CrossRef] [PubMed]

23. Kingston-Smith, A.H.; Theodorou, M.K. Post-ingestion metabolism of fresh forage. New Phytol. 2000, 148, 37-55. [CrossRef]

24. Kingston-Smith, A.H.; Bollard, A.L.; Thomas, B.J.; Brooks, A.E.; Theodorou, M.K. Nutrient availability during the early stages of colonization of fresh forage by rumen micro-organisms. New Phytol. 2003, 158, 119-130. [CrossRef]

25. Lees, G.L.; Howarth, R.E.; Goplen, B.P. Morphological characteristics of leaves from some legume forages: Relation to digestion and mechanical strength. Can. J. Bot. 1982, 60, 2126-2132. [CrossRef]

26. Howarth, R.E.; Golpen, B.P.; Brandt, S.A.; Cheng, K.J. Disruption of leaf tissue by rumen microorganisms: An approach to breeding to breeding bloat-safe forage legumes. Crop Sci. 1982, 22, 564-568. [CrossRef]

27. Pichard, G.R.; Tesser, B.R.; Vives, C.; Solari, C.; Hott, A.; Larrain, R.E. Proteolysis and characterization of peptidases in forage plants. Agron. J. 2006, 98, 1392-1399. [CrossRef]

28. Attwood, G.T. The contribution of plant-derived proteinases to the breakdown of fresh pasture protein in the rumen. Br. J. Nutr. 2005, 93, 421-423. [CrossRef] [PubMed]

29. Cheng, K.J.; Fay, J.P.; Howarth, R.E.; Costerton, J.W. Sequence of events in the digestion of fresh legume leaves by rumen bacteria. Appl. Environ. Microbiol. 1980, 40, 613-625. [PubMed]

30. McAllister, T.A.; Bae, H.D.; Jones, G.A.; Cheng, K.J. Microbial attachment and feed digestion in the rumen. J. Anim. Sci. 1994, 72, 3004-3018. [PubMed]

31. Howarth, R.E.; Goplen, B.P.; Fay, J.P.; Cheng, K.J. Digestion of bloat-causing and bloat-safe legumes. Ann. Rech. Vet. 1979, 10, 332-334. [PubMed] 
32. Aufrère, J.; Dudilieu, M.; Poncet, C. In vivo and in situ measurements of the digestive characteristics of sainfoin in comparison with lucerne fed to sheep as fresh forages at two growth stages and as hay. Animal 2008, 2, 1331-1339. [CrossRef] [PubMed]

33. Howarth, R.E. A review of bloat in cattle. Can. Vet. J. 1975, 16, 281-294. [PubMed]

34. Gesshe, R.H.; Walton, P.D. Grazing animal preferences for cultivated forages in Canada. J. Range Manag. 1981, 34, 42-45. [CrossRef]

35. Tamminga, S.; Van Straalen, W.M.; Subnel, A.P.J.; Meijer, R.G.M.; Steg, A.; Wever, C.J.G.; Blok, M.C. The Dutch protein evaluation system: The DVE/OEB-system. Livest. Prod. Sci. 1994, 40, 139-155. [CrossRef]

36. Broderick, G.A.; Huhtanen, P.; Ahvenjärvi, S.; Reynal, S.M.; Shingfield, K.J. Quantifying ruminal nitrogen metabolism using the omasal sampling technique in cattle-A meta-analysis. J. Dairy Sci. 2010, 93, 3216-3230. [CrossRef] [PubMed]

37. Bergman, E.N. Energy contributions of volatile fatty acids from the gastrointestinal tract in various species. Physiol. Rev. 1990, 70, 567-590. [PubMed]

38. Hoover, W.H.; Stokes, S.R. Balancing carbohydrates and proteins for optimum rumen microbial yield. J. Dairy Sci. 1991, 74, 3630-3644. [CrossRef]

39. Beever, D.E.; Dhanoa, M.S.; Losada, H.R.; Evans, R.T.; Cammell, S.B.; France, J. The effect of forage species and stage of harvest on the processes of digestion occurring in the rumen of cattle. Br. J. Nutr. 1986, 56, 439-454. [CrossRef] [PubMed]

40. Czerkawski, J.W. An Introduction to Rumen Studies; Pergamon Press Ltd.: Oxford, UK, 1986.

41. Tamminga, S.; van Vuuren, A.M.; van der Koelen, C.J.; Ketelaar, R.S.; van der Togt, P.L. Ruminal behaviour of structural carbohydrates, non-structural carbohydrates and crude protein from concentrate ingredients in dairy cows. Neth. J. Agric. Sci. 1990, 38, 513-526.

42. Sinclair, L.A.; Galbraith, H.; Scaife, J.R. Effect of dietary protein concentration and cimaterol on growth and body composition of entire male lambs. Anim. Feed Sci. Technol. 1991, 34, 181-192. [CrossRef]

43. NRC. National Research Council. Nutrient Requirements of Dairy Cattle, 7th revised ed.; National Academy Press: Washington, DC, USA, 2001.

44. Aufrère, J.; Graviou, D.; Baumont, R.; Detour, A.; Demarquilly, C. Degradation in the rumen of proteins from fresh lucerne forage in various stages of growth and conserved as silage or hay. Ann. Zootech. 2000, 49, 461-474. [CrossRef]

45. Elizalde, J.C.; Merchen, N.R.; Faulkner, D.B. In situ dry matter and crude protein degradation of fresh forages during the spring growth. J. Dairy Sci. 1999, 82, 1978-1990. [CrossRef]

46. Faría-Mármol, J.; González, J.; Rodríguez, C.A.; Alvir, M.R. Effect of diet forage to concentrate ratio on rumen degradability and post-ruminal availability of protein from fresh and dried lucerne. Anim. Sci. 2002, 74, 337-345.

47. González, J.; Faría-Mármol, J.; Rodriguez, C.A.; Alvir, M.R. Effects of stage of harvest on the protein value of fresh lucerne for ruminants. Reprod. Nutr. Dev. 2001, 41, 381-392. [CrossRef] [PubMed]

48. Yari, M.; Valizadeha, R.; Naseriana, A.A.; Jonker, A.A.A.; Yu, P. Modeling nutrient avalilability of alfalfa hay harvested at three stages of maturity and in the afternoon and morning in dairy cows. Anim. Feed Sci. Technol. 2012, 178, 12-19. [CrossRef]

49. Tamminga, S. Protein degradation in the forestomachs of ruminants. J. Anim. Sci. 1979, 49, 1615-1630.

50. Kaneda, T. Iso- and anteiso-fatty acids in bacteria: Biosynthesis, function, and taxonomic significance. Microbiol. Rev. 1991, 55, 288-302. [PubMed]

51. Van Duinkerken, G.; Andre, G.; Smits, M.C.J.; Monteny, G.J.; Sebek, L.B.J. Effect of rumen degradable protein balance and forage type on bulk milk urea concentration and emission of ammonia from dairy cow houses. J. Dairy Sci. 2005, 88, 1099-1112. [CrossRef]

52. Tamminga, $\mathrm{S}$. The effect of the supply of rumen degradable protein and metabolizable protein on negative energy balance and fertility in dairy cows. Anim. Reprod. Sci. 2006, 96, 227-239. [CrossRef] [PubMed]

53. Rémond, D.; Meschy, F.; Boivin, R. Metabolites, water and mineral exchanges across the rumen wall: Mechanisms and regulation. Ann. Zootech. 1996, 45, 97-119. [CrossRef]

54. Lapierre, H.; Lobley, G.E. Nitrogen recycling in the ruminant: A review. J. Dairy Sci. 2001, 84, E223-E236. [CrossRef]

55. Lapierre, H.; Berthiaume, R.; Raggio, G.; Thivierge, M.C.; Doepel, L.; Pacheco, D.; Dubreuil, D.; Lobley, G.E. The route of absorbed nitrogen into milk protein. Anim. Sci. 2005, 80, 11-22. [CrossRef] 
56. Hoekstra, N.J.; Schulte, R.P.O.; Struik, P.C.; Lantinga, E.A. Pathways to improving the N efficiency of grazing bovines. Eur. J. Agron. 2007, 26, 363-374. [CrossRef]

57. Valkeners, D.; Thewis, A.; Piron, F.; Beckers, Y. Effect of imbalance between energy and nitrogen supplies on microbial protein synthesis and nitrogen metabolism in growing double-muscled Belgian blue bulls. J. Anim. Sci. 2004, 82, 1818-1825. [PubMed]

58. Cole, N.A. Nitrogen retention by lambs fed oscillating dietary protein concentrations. J. Anim. Sci. 1999, 77, 215-222. [PubMed]

59. Archibeque, S.L.; Freetly, H.C.; Cole, N.A.; Ferrell, C.L. The influence of oscillating dietary protein concentrations on finishing cattle. II. Nutrient retention and ammonia emissions. J. Anim. Sci. 2007, 85, 1496-1503. [CrossRef] [PubMed]

60. Kiran, D.; Penner, G.B.; Mutsvangwa, T. Feeding oscillating dietary crude protein concentrations increases nitrogen utilization in growing lambs and this response is partly attributable to increased urea transfer to the rumen. J. Nutr. 2011, 141, 560-567.

61. Tamminga, S.; Brandsma, G.G.; Dijksta, J.; Duinkerken, G.V.; Vuuren, A.M.V.; Blok, M.C. Protein Evaluation for Ruminants: The DVE/OEB 2007 System, CVB Documentation Report nr. 53; Centraal Veevoeder Bureau: Lelystad, The Netherlands, 2007.

62. Dhiman, T.R.; Satter, L.D. Protein as the first-limiting nutrient for lactating dairy cows fed high proportions of good quality alfalfa silage. J. Dairy Sci. 1993, 76, 1960-1971. [CrossRef]

63. Klopfenstein, T. Need for escape protein by grazing cattle. Anim. Feed Sci. Technol. 1996, 60, $191-199$. [CrossRef]

64. Cockrem, F.R.M.; Mclntosh, J.T.; McLaren, R.D.; Morris, C.A. In vitro gas and foam production by rumen fluid from cows of genetically high or low susceptibility to pasture bloat. Anim. Prod. 1987, 45, 37-42. [CrossRef]

65. Tanner, G.J.; Moate, P.J.; Davis, L.A.; Laby, R.H.; Yuguang, L.; Larkin, P.J. Proanthocyanidins (condensed tannin) destabilize plant protein foams in a dose dependent manner. Aust. J. Agric. Res. 1995, 46, 1101-1109. [CrossRef]

66. Clarke, R.T.J.; Reid, C.S.W. Foamy bloat of cattle. A review. J. Dairy Sci. 1974, 57, 753-785. [CrossRef]

67. Cheng, K.J.; McAllister, T.A.; Popp, J.D.; Hristov, A.N.; Mir, Z.; Shin, H.T. A review of bloat in feedlot cattle. J. Anim. Sci. 1998, 76, 299-308. [PubMed]

68. Howarth, R.E.; Cheng, K.J.; Majak, W.; Costerton, J.W. Ruminant bloat. 516-527. In Control of digestion and metabolism in ruminants. Proceedings of the Sixth International Symposium Physiology, Banff, AB, Canada, 10-14 September 1984; Miligan, L.P., Grovum, W.L., Dobson, A., Eds.; Prentice-Hall: Engelwood Cliffs, NJ, USA, 1986.

69. Majak, W.; McAllister, T.A.; McCartney, D.; Stanford, K.; Cheng, K.J. Bloat in Cattle; Information Packaging Centre, Alberta Agriculture, Food and Rural Development: Edmonton, AB, Canada, 2003.

70. Clark, J.H.; Klusmeyer, T.H.; Cameron, M.R. Microbial protein synthesis and flows of nitrogen fractions to the duodenum of dairy cows. J. Dairy Sci. 1992, 75, 2304-2323. [CrossRef]

71. Majak, W.; Hall, J.W.; Rode, L.M.; Kalnin, C.M. Rumen clearance rates in relation to the occurrence of alfalfa bloat in cattle. I. Passage of water-soluble markers. J. Dairy Sci. 1986, 69, 1560-1567. [CrossRef]

72. Majak, W.; Hall, J.W.; McCaughey, W.P. Pasture management strategies for reducing the risk of legume bloat in cattle. J. Anim. Sci. 1995, 73, 1493-1498. [PubMed]

73. Mangan, J.L. Bloat in cattle. XVI. Bovine salival: The chemical composition of the parotid, submaxillary and residual secretions. N. Z. J. Agric. Res. 1958, 2, 990-1001.

74. Mendel, V.E.; Boda, J.M. Physiological studies of the rumen with emphasis on the animal factors associated with bloat. J. Dairy Sci. 1961, 44, 1881-1898. [CrossRef]

75. Majak, W.; Howarth, R.E.; Cheng, K.J.; Hall, W.J. Rumen conditions that predispose cattle to pasture bloat. J. Dairy Sci. 1983, 66, 1683. [CrossRef]

76. Hall, J.W.; Majak, W.; van Ryswyk, A.L.; Howarth, R.E.; Kalnin, C.M. The relationship of rumen cations and soluble protein with predisposition of cattle to alfalfa bloat. Can. J. Anim. Sci. 1988, 68, 431-437. [CrossRef]

77. Gutierrez, J.; Davis, R.E.; Lindahl, I.L. Some chemical and physical properties of a slime from the rumen of cattle. Appl. Microbiol. 1961, 9, 209-212. [PubMed]

78. Meyer, R.M.; Bartley, E.E. Bloat in cattle. XV. The relation of viscosity and cell-free polysaccharide content of rumen fluid to feedlot bloat. J. Anim. Sci. 1971, 33, 1018-1021. [PubMed] 
79. Gutierrez, J.; Essig, H.W.; Williams, P.P.; Davis, R.E. Properties of a slime isolated from the rumen fluid of cattle bloating on clover pasture. J. Anim. Sci. 1963, 22, 506-509.

80. Min, B.R.; Pinchak, W.E.; Anderson, R.C.; Hume, M.E. In vitro bacterial growth and in vivo ruminal microbiota populations associated with bloat in steers grazing wheat forage. J. Anim. Sci. 2006, 84, 2873-2882. [CrossRef] [PubMed]

81. Majak, W.; Howarth, R.E.; Narasimhalu, P. Chlorophyll and protein levels in bovine rumen fluid in relation to alfalfa pasture bloat. Can. J. Anim. Sci. 1985, 65, 147-156. [CrossRef]

82. Gutierrez, J.; Davis, R.E. Isolation of saponin-digesting bacteria from the rumen of bloating cattle on ladino clover pasture. J. Anim. Sci. 1962, 21, 819-823.

83. Clauss, M.; Hummel, J.; Streich, W.J. The dissociation of the fluid and particle phase in the forestomach as a physiological characteristic of large grazing ruminants: An evaluation of available, comparable ruminant passage data. Eur. J. Wildl. Res. 2006, 52, 88-98. [CrossRef]

84. Bartley, E.E.; Bassette, R. Bloat in cattle. III. Composition of foam in legume bloat. J. Dairy Sci. 1961, 44, 365-366. [CrossRef]

85. Lees, G.L. Condensed tannins in some forage legumes. Basic Life Sci. 1992, 59, 915-934. [PubMed]

86. Attwood, G.T.; Reilly, K. Identification of proteolytic rumen bacteria isolated from New Zealand cattle. J. Appl. Microbiol. 1995, 79, 22-29. [CrossRef]

87. Mangan, J.L. Bloat in cattle. XI. The foaming properties of proteins, saponins and rumen liquor. N. Z. J. Agric. Res. 1959, 2, 47-61. [CrossRef]

88. Pressey, R.; Synhorst, S.H.; Bertram, J.; Allen, R.S.; Jacobson, N.L. Foaming properties of alfalfa and their relationship to bloat. J. Anim. Sci. 1963, 22, 970-978.

89. Thompson, D.J.; Brooke, B.M.; Garland, G.J.; Hall, J.W.; Majak, W. Effect of stage of growth of alfalfa on the incidence of bloat in cattle. Can. J. Anim. Sci. 2000, 80, 725-727. [CrossRef]

90. Luckett, C.R.; Klopfenstein, T.J. Leaf to stem ratio and composition of alfalfa from five harvesting systems. J. Anim. Sci. 1970, 31, 126-129.

91. Gutek, L.H.; Goplen, B.P.; Howarth, R.E.; McArthur, J.M. Variation of soluble proteins in alfalfa, sainfoin, and birdsfoot trefoil. Crop Sci. 1974, 14, 495-499. [CrossRef]

92. Hall, J.W.; Majak, W. Plant and Animal Factors in Legume Bloat; CRC Press: Boca Raton, FL, USA, 1989.

93. Rook, A.J. Principles of Foraging and Grazing Behaviour; Blackwell Science: Oxford, UK, 2000.

94. Cooper, C.S.; Eslick, R.F.; McDonald, P.W. Foam formation from extracts of 27 legume species in vitro. Crop Sci. 1966, 6, 215-216. [CrossRef]

95. Tremblay, G.F.; Bélanger, G.; McRae, K.B.; Michaud, R. Leaf and stem dry matter digestibility and ruminal undegradable proteins of alfalfa cultivars. Can. J. Plant Sci. 2002, 82, 383-393. [CrossRef]

96. Pedersen, M.W.; Zimmer, D.E.; McAllister, D.R.; Anderson, J.O.; Wilding, M.D.; Taylor, G.A.; McGuire, C.F. Comparative studies of saponin of several alfalfa varieties using chemical and biochemical assays. Crop Sci. 1967, 7, 349-352. [CrossRef]

97. Klita, P.T.; Mathison, G.W.; Fenton, T.W.; Hardin, R.T. Effects of alfalfa root saponins on digestive function in sheep. J. Anim. Sci. 1996, 74, 1144-1156. [PubMed]

98. Mathison, G.W.; Soofi-Siawash, R.; Klita, P.T.; Okine, E.K.; Sedgwick, G. Degradability of alfalfa saponins in the digestive tract of sheep and their rate of accumulation in rumen fluid. Can. J. Anim. Sci. 1999, 79, 315-319. [CrossRef]

99. Ferguson, W.S.; Terry, R.A. Bloat investigations. J. Agric. Sci. 1955, 46, 257-266. [CrossRef]

100. Majak, W.; Howarth, R.E.; Fesser, A.C.; Goplen, B.P.; Pedersen, M.W. Relationship between ruminant bloat and the composition of alfalfa herbage. II. Saponins. Can. J. Anim. Sci. 1980, 60, 699-708. [CrossRef]

101. Min, B.R.; Pinchak, W.E.; Mathews, D.; Fulford, J.D. In vitro rumen fermentation and in vivo bloat dynamics of steers grazing winter wheat to corn oil supplementation. Anim. Feed Sci. Technol. 2007, 133, 192-205. [CrossRef]

102. Akins, M.S.; Kegley, E.B.; Coffey, K.P.; Caldwell, J.D.; Lusby, K.S.; Moore, J.C.; Coblentz, W.K. Comparison of bloat potential between a variety of soft-red versus a variety of hard-red winter wheat forage. J. Anim. Sci. 2009, 87, 3278-3287. [CrossRef] [PubMed]

103. Lindahl, I.L.; Cook, A.C.; Davis, R.E.; Maclay, W.D. Preliminary investigations on the role of alfalfa saponin in ruminant bloat. Science 1954, 119, 157-158. [CrossRef] [PubMed] 
104. Pedersen, M.W.; Berrang, B.; Wall, M.E.; Davis, K.H., Jr. Modification of saponin characteristics of alfalfa by selection. Crop Sci. 1973, 13, 731-735. [CrossRef]

105. Sen, S.; Makkar, H.P.S.; Becker, K. Alfalfa saponins and their implication in animal nutrition. J. Agric. Food Chem. 1998, 46, 131-140. [CrossRef] [PubMed]

106. Buckingham, J.H. Effect of $\mathrm{pH}$, concentration and temperature on the strength of cytoplasmic protein foams. J. Sci. Food Agric. 1970, 21, 441-445. [CrossRef]

107. Wang, J.C.; Kinsella, J.E. Functional properties of alfalfa leaf protein: Foaming. J. Food Sci. 1976, 41, 498-501. [CrossRef]

108. Stifel, F.B.; Vetter, R.L.; Allen, R.S. Relation between calcium and magnesium binding to fraction I chloroplast protein and bloat. J. Agric. Food Chem. 1968, 16, 500-504. [CrossRef]

109. Conrad, H.R.; Pounden, W.D.; Bentley, O.G.; Fetter, A.W. Production of gas in rumen fermentations and stable mass formation from alfalfa fiber and pectic substances. J. Dairy Sci. 1958, 41, 1586-1592. [CrossRef]

110. Jung, H.G.; Mertens, D.R.; Payne, A.J. Correlation of acid detergent lignin and Klason lignin with digestibility of forage dry matter and neutral detergent fiber. J. Dairy Sci. 1997, 80, 1622-1628. [CrossRef]

111. Majak, W.; Hall, J.W.; McAllister, T.A. Practical measures for reducing risk of alfalfa bloat in cattle. J. Range Manag. 2001, 54, 490-493. [CrossRef]

112. Stifel, F.B.; Vetter, R.L.; Allen, R.S.; Horner, H.T. Chemical and utrastructural relationships between alfalfa leaf chloroplasts and bloat. Phytochemistry 1968, 7, 355-364. [CrossRef]

113. Bretschneider, G.; Peralta, M.; Santini, F.J.; Fay, J.P.; Faverin, C. Influence of corn silage supplementation before alfalfa grazing on ruminal environment in relation to the occurrence of frothy bloat in cattle. Anim. Feed Sci. Technol. 2007, 136, 23-37. [CrossRef]

114. Majak, W.; Garland, G.J.; Lysyk, T.J. The effect of feeding hay before fresh alfalfa on the occurrence of frothy bloat in cattle. Can. J. Anim. Sci. 2008, 88, 29-31. [CrossRef]

115. Majak, W.; Garland, G.J.; Lysyk, T.J. The effect of herbage mixtures of alfalfa and orchardgrass on the incidence of bloat in cattle. Can. J. Anim. Sci. 2003, 83, 827-829. [CrossRef]

116. Veira, D.M.; Lysyk, T.J.; Thompson, D.J.; Garland, G.J.; Majak, W. Effect of grazing mixtures of alfalfa and orchardgrass grown in strips on the incidence of bloat in cattle. Can. J. Anim. Sci. 2010, 90, 109-112. [CrossRef]

117. Rutter, S.M. Diet preference for grass and legumes in free-ranging domestic sheep and cattle: Current theory and future application. Appl. Anim. Behav. Sci. 2006, 97, 17-35. [CrossRef]

118. Coulman, B.; Goplen, B.; Majak, W.; McAllister, T.A.; Cheng, K.J.; Berg, B.; Hall, J.W.; McCartney, D.; Acharya, S.N. A review of the development of a bloat-reduced alfalfa cultivar. Can. J. Plant Sci. 2000, 80, 487-491. [CrossRef]

119. Goplen, B.P.; Howarth, R.E.; Lees, G.L. Selection of alfalfa for a lower initial rate of digestion and corresponding changes in epidermal and mesophyll cell wall thickness. Can. J. Plant Sci. 1993, 73, 111-122. [CrossRef]

120. Coulman, B.; Duncan, C.; Goplen, B.P. Response to four cycles of selection for low initial rate of digestion in alfalfa. In Proceedings of the 36th North American Alfalfa Improvement Conference (NAAIC), Bozeman, MT, USA, 2-6 August 1998; Bouton, J., Bauchan, G., Eds.; pp. 59-60.

121. Tremblay, G.F.; Michaud, R.; Bélanger, G.; McRae, K.B.; Petit, H.V. In vitro ruminal undegradable proteins of alfalfa cultivars. Can. J. Plant Sci. 2000, 80, 315-325. [CrossRef]

122. Berg, P.B.; Majak, W.; McAllister, T.; Hall, J.W.; McCartney, D.; Coulman, B.E.; Goplen, G.P.; Acharya, S.N.; Tait, R.M.; Cheng, K.J. Bloat in cattle grazing alfalfa cultivars selected for a low initial rate of digestion: A review. Can. J. Plant Sci. 2000, 80, 493-502. [CrossRef]

123. Jonker, A.; Gruber, M.Y.; Wang, Y.; Coulman, B.; McKinnon, J.J.; Christensen, D.A.; Yu, P. Foam stability of leaves from anthocyanidin-accumulating $L c$-Alfalfa and relation to molecular structures detected by FTIR vibration spectroscopy. Grass Forage Sci. 2012, 67, 369-381. [CrossRef]

124. Basigalup, D.H.; Castell, C.V.; Giaveno, C.D. Response to selection for lower initial rate of dry matter disappearance in the development of a bloat-tolerant non-dormant alfalfa population. J. Genet. Breed. 2003, $57,31-38$.

125. Bernaldez, M.L.; Basigalup, D.H.; Ferrer, J.M.; Balzarini, M.; Alomar, D. Bloat reduction potential of an alfalfa cultivar selected for low initial ruminal disappearance. Crop Sci. 2009, 49, 356-361. [CrossRef] 
126. Broderick, G.A.; Buxton, D.R. Genetic variation in alfalfa for ruminal protein degradability. Can. J. Plant. Sci. 1991, 71, 755-760. [CrossRef]

127. Tremblay, G.F.; Michaud, R.; Bélanger, G. Protein fractions and ruminal undegradable proteins in alfalfa. Can. J. Plant Sci. 2003, 83, 555-559. [CrossRef]

128. Tabe, L.M.; Higgins, C.M.; McNabb, W.C.; Higgins, T.J.V. Genetic engineering of grain and pasture legumes for improved nutritive value. Genetica 1993, 90, 181-200. [CrossRef] [PubMed]

129. Tabe, L.M.; Wardley-Richardson, T.; Ceriotti, A.; Aryan, A.; McNabb, W.; Moore, A.; Higgins, T.J. A biotechnological approach to improving the nutritive value of alfalfa. J. Anim. Sci. 1995, 73, 2752-2759. [PubMed]

130. Ørskov, E.R. Protein Nutrition in Ruminants, 2nd ed.; Academic Press, Inc.: San Diego, CA, USA, 1986.

131. McNabb, W.C.; Spencer, D.; Higgins, T.J.; Barry, T.N. In vitro rates of rumen proteolysis of ribulose-1,5-bisphosphate carboxylase (Rubisco) from lucerne leaves, and of ovalbumin, vicilin and sunflower albumin 8 storage proteins. J. Sci. Food Agric. 1994, 64, 53-61. [CrossRef]

132. Doiron, K.J.; Yu, P.; McKinnon, J.J.; Christensen, D.A. Heat-induced protein structure and sub-fractions in relation to protein degradation kinetics and intestinal availability in dairy cattle. J. Dairy Sci. 2009, 92, 3319-3330. [CrossRef] [PubMed]

133. Yu, P.; Nuez-Ortín, W.G. Relationship of protein molecular structure to metabolizable proteins in different types of dried distillers grains with solubles: A novel approach. Br. J. Nutr. 2010, 104, 1429-1437. [CrossRef] [PubMed]

134. Jonker, A.; Gruber, M.Y.; Wang, Y.; Coulman, B.; Azarfar, A.; McKinnon, J.J.; Christensen, D.A.; Yu, P. Modeling degradation ratios and nutrient availability of anthocyanidin-accumulating $L c$-alfalfa populations in dairy cows. J. Dairy Sci. 2011, 94, 1430-1444. [CrossRef] [PubMed]

135. Yu, P.; Jonker, A.; Gruber, M. Molecular basis of protein structure and nutritive value in proanthocyanidin-enhanced $L c$-transgenic alfalfa using synchrotron-radiation FTIR microspectroscopy. Spectrochim. Acta Part A 2009, 73, 846-853. [CrossRef] [PubMed]

136. Jonker, A.; Gruber, M.Y.; Wang, Y.; Narvaez, N.; Coulman, B.; McKinnon, J.J.; Christensen, D.A.; Azarfar, A.; $\mathrm{Yu}, \mathrm{P}$. Fermentation, degradation and microbial nitrogen partitioning for three forage color phenotypes within anthocyanidin-accumulating Lc-alfalfa progeny. J. Sci. Food Agric. 2012, 92, 2265-2273. [CrossRef] [PubMed]

137. Yari, M.; Valizadeha, R.; Naseriana, A.A.; Jonker, A.; Yu, P. Protein molecular structures in alfalfa hay cut at three stages of maturity and in the afternoon and morning and relationship with nutrient availability in ruminants. J. Sci. Food Agric. 2013, 93, 3072-3080. [CrossRef] [PubMed]

138. Chen, D.; Peel, M.D.; Olson, K.C.; Weimer, B.C.; DeWald, D.B. Differential ruminal degradation of alfalfa proteins. Can. J. Plant Sci. 2009, 89, 1065-1074. [CrossRef]

139. Tanner, G.J.; Moore, A.E.; Larkin, P.J. Proanthocyanidins inhibit hydrolysis of leaf proteins by rumen microflora in vitro. Br. J. Nutr. 1994, 71, 947. [CrossRef] [PubMed]

140. Min, B.R.; McNabb, W.C.; Barry, T.N.; Peters, J.S. Solubilization and degradation of ribulose-1,5-bisphosphate carboxylase/oxygenase (EC 4.1.1.39; Rubisco) protein from white clover (Trifolium repens) and Lotus corniculatus by rumen microorganisms and the effect of condensed tannins on these processes. J. Agric. Sci. 2000, 134, 305-317. [CrossRef]

141. Wang, Y.; Berg, B.P.; Barbier, L.R.; Veira, D.M.; McAllister, T.A. Comparison of alfalfa and mixed alfalfa-sainfoin pastures for grazing cattle: Effects on incidence of bloat, ruminal fermentation, and feed intake. Can. J. Anim. Sci. 2006, 86, 383-392. [CrossRef]

142. McMahon, L.R.; Majak, W.; McAllister, T.A.; Hall, J.W.; Jones, G.A.; Popp, J.D.; Cheng, K.J. Effect of sainfoin on in vitro digestion of fresh alfalfa and bloat in steers. Can. J. Anim. Sci. 1999, 79, 203-212. [CrossRef]

143. Douglas, G.B.; Wang, Y.; Waghorn, G.C.; Barry, T.N.; Purchas, R.W.; Foote, A.G.; Wilson, G.F. Liveweight gain and wool production of sheep grazing Lotus corniculatus and lucerne (Medicago sativa). N. Z. J. Agric. Res. 1995, 38, 95-104. [CrossRef]

144. Barry, T.N.; Manley, T.R. Interrelationships between the concentrations of total condensed tannin, free condensed tannin and lignin in Lotus sp. and their possible consequences in ruminant nutrition. J. Sci. Food Agric. 1986, 37, 248-254. [CrossRef] 
145. Min, B.R.; Barry, T.N.; McNabb, W.C.; Kemp, P.D. Effect of condensed tannins on the production of wool and on its processing characteristics in sheep grazing Lotus corniculatus. Aust. J. Agric. Res. 1998, 49, 597-605. [CrossRef]

146. Wang, Y.; Douglas, G.B.; Waghorn, G.C.; Barry, T.N.; Foote, A.G. Effects of condensed tannins in Lotus corniculatus upon lactation performance in ewes. J. Agric. Sci. 1996, 126, 353-362. [CrossRef]

147. Wang, Y.; Douglas, G.B.; Waghorn, G.C.; Barry, T.N.; Foote, A.G.; Purchas, R.W. Effect of condensed tannins upon the performance of lambs grazing Lotus corniculatus and lucerne (Medicago sativa). J. Agric. Sci. 1996, 126, 87-98. [CrossRef]

148. Min, B.R.; McNabb, W.C.; Barry, T.N.; Kemp, P.D.; Waghorn, G.C.; McDonald, M.F. The effect of condensed tannins in Lotus corniculatus upon reproductive efficiency and wool production in sheep during late summer and autumn. J. Agric. Sci. 1999, 132, 323-334. [CrossRef]

149. Ramírez-Restrepo, C.A.; Barry, T.N.; López-Villalobos, N.; Kemp, P.D.; Harvey, T.G. Use of Lotus corniculatus containing condensed tannins to increase reproductive efficiency in ewes under commercial dryland farming conditions. Anim. Feed Sci. Technol. 2005, 121, 23-43. [CrossRef]

150. Ramírez-Restrepo, C.A.; Barry, T.N.; Pomroy, W.E.; López-Villalobos, N.; McNabb, W.C.; Kemp, P.D. Use of Lotus corniculatus containing condensed tannins to increase summer lamb growth under commercial dryland farming conditions with minimal anthelmintic drench input. Anim. Feed Sci. Technol. 2005, 122, 197-217. [CrossRef]

151. Min, B.R.; Hart, S.P. Tannins for suppression of internal parasites. J. Anim. Sci. 2003, 81, E102-E109.

152. Woodward, S.L.; Waghorn, G.C.; Watkins, K.A.; Bryant, M.A. Feeding birdsfoot trefoil (Lotus corniculatus) reduces the environmental impact of dairy farms. Proc. N. Z. Soc. Anim. Prod. 2009, 69, 179-183.

153. Woodward, S.L.; Waghhorn, G.C.; Laboyrie, P.G. Condensed tannins in birdsfoot trefoil (Lotus corniculatus) reduce methane emissions from dairy cows. Proc. N. Z. Soc. Anim. Prod. 2004, 64, 160-164.

154. Harris, S.L.; Clark, A.D.; Laboyrie, P.J. Birsdfoot trefoil-An alternative legume for New Zealand dairy pastures. Proc. N. Z. Soc. Anim. Prod. 1998, 60, 99-103.

155. Woodward, S.L.; Auldist, M.J.; Laboyrie, P.J.; Jansen, E.B.L. Effect of Lotus corniculatus and condensed tannins on milk yield and milk composition of dairy cows. Proc. N. Z. Soc. Anim. Prod. 1999, 59, 152.

156. Turner, S.A.; Waghhorn, G.C.; Woodward, S.L.; Thomson, N.A. Condensed tannins in birdsfoot trefoil (Lotus corniculatus) affect the detailed composition of milk from dairy cows. Proc. N. Z. Soc. Anim. Prod. 2005, 65, 283-289.

157. Wen, L.; Kallenbach, R.L.; Williams, J.E.; Roberts, C.A.; Beuselinck, P.R.; McGraw, R.L.; Benedict, H.R. Performance of steers grazing rhizomatous and nonrhizomatous birdsfoot trefoil in pure stands and in tall fescue mixtures. J. Anim. Sci. 2002, 80, 1970-1976. [PubMed]

158. Quattrocchio, F.; Baudry, A.; Lepiniec, L.; Grotewold, E. The regulation of flavonoid biosynthesis. In The Science of Flavonoids; Grotewold, E., Ed.; Springer Science Business Media, Inc.: New York, NY, USA, 2006; pp. 97-122.

159. Robbins, M.P.; Paolocci, F.; Hughes, J.W.; Turchetti, V.; Allison, G.; Arcioni, S.; Morris, P.; Damiani, F. Sn, a maize $\beta H L H$ gene, modulates anthocyanin and condensed tannin pathways in Lotus corniculatus. J. Exp. Bot. 2003, 54, 239-248. [CrossRef] [PubMed]

160. Koupai-Abyazani, M.R.; McCallum, J.; Muir, A.D.; Lees, G.L.; Bohm, B.A.; Towers, G.H.N.; Gruber, M.Y. Purification and characterization of a proanthocyanidin polymer from seed of alfalfa (Medicago sativa cv. Beaver). J. Agric. Food Chem. 1993, 41, 565-569. [CrossRef]

161. Peel, G.J.; Pang, Y.; Modolo, L.V.; Dixon, R.A. The LAP1 MYB transcription factor orchestrates anthocyanidin biosynthesis and glycosylation in Medicago. Plant J. 2009, 59, 136-149. [CrossRef] [PubMed]

162. Ray, H.; Yu, M.; Auser, P.; Blahut-Beatty, L.; McKersie, B.; Bowley, S.; Westcott, N.; Coulman, B.; Lloyd, A.; Gruber, M.Y. Expression of anthocyanins and proanthocyanidins after transformation of alfalfa with maize Lc. Plant Physiol. 2003, 132, 1448-1463. [CrossRef] [PubMed]

163. Wang, Y.; Frutos, P.; Gruber, M.Y.; Ray, H.; McAllister, T.A. In vitro ruminal digestion of anthocyanidin-containing alfalfa transformed with the maize Lc regulatory gene. Can. J. Plant Sci. 2006, 86, 1119-1130. [CrossRef] 
164. Jonker, A.; Gruber, M.Y.; McCaslin, M.; Wang, Y.; Coulman, B.; McKinnon, J.J.; Christensen, D.A.; Yu, P. Nutrient composition and degradation profiles of anthocyanidin-accumulating $L c$-alfalfa populations. Can. J. Anim. Sci. 2010, 90, 401-412. [CrossRef]

165. He, F.; Pan, Q.H.; Shi, Y.; Duan, C.Q. Biosynthesis and genetic regulation of proanthocyanidins in plants. Molecules 2008, 13, 2674-2703. [CrossRef] [PubMed]

166. Heendeniya, R.; Gruber, M.Y.; Yu, P.; University of Saskatchewan and AAFC, Saskatoon, Canada. unpublished data. 2016.

(C) 2016 by the authors; licensee MDPI, Basel, Switzerland. This article is an open access article distributed under the terms and conditions of the Creative Commons Attribution (CC-BY) license (http://creativecommons.org/licenses/by/4.0/). 